\title{
Government Policy about Workers Terminated due Covid-19 Pandemic
}

\author{
I Dewa Ayu Widyani ${ }^{1}$, Erni Murniarti ${ }^{2}$ \\ \{dewaayua@ymail.com¹, erni.murniarti@uki.ac.id² \\ Faculty of Law, Universitas Kristen Indonesia ${ }^{1}$ \\ Magister Educational Administration, Universitas Kristen Indonesia ${ }^{2}$
}

\begin{abstract}
Termination of employment for workers, they are given their rights in the form of severance pay and long service awards. However, during the Covid-19 pandemic, which resulted in workers being terminated from their employment relationship, their rights were not fully granted or even not granted, because employers experienced losses in their business due to government regulations regarding Social Restrictions. This literature review aims to analyses government policies regarding the rights of workers who experience layoffs and educate the public about their rights in this regard. To protect workers who have lost their jobs, resulting in the loss of a source of livelihood for them and their families, the Government has issued several policies to protect workers, including Pre-Employment Cards, Incentives and Cash-Intensive Programs through the Village Head. Thus, it is hoped that workers will be helped to get new jobs independently or work for other companies according to the skills obtained from job training provided by the government.
\end{abstract}

Keywords: Government Policy; Termination of Employment; Covid-19 Pandemic

\section{Introduction}

To provide and survival the needs of family life, a person needs to work, either independently or work for others to get wages or salaries. According to UUD number 13 in 2003[1] concerning Manpower (hereinafter referred to as the Manpower Act) refers to it as a Worker/Labourer, i.e. any person who works by receiving wages or other forms of remuneration [2]. Moreover, Imam Soepomo [3] said that a worker/labourer is someone who works for other people for wages. Employer is an individual entrepreneur or legal entity that employs workers/laborers by paying wages/rewards in other forms. Manpower in several countries, including Indonesia, is an important asset for the country, because it provides income for the country concerned. For this reason, Indonesian law stipulates that the position of Workers/Labourers and employers is equal, workers are free, because no one may be enslaved in slavery, because all forms and types of slavery, extension, slavery and forced labour are prohibited, because they are not in accordance to Pancasila and Constitution of the Republic of Indonesia 1945 Article 27 [4].

Legally, the position of the worker/labourer and the entrepreneur is the same but socially and economically not the same, the worker/labourer is under the orders of the employer/employer, so protection is needed for the worker/labourer. which requires or compels employers/entrepreneurs to act under the law, the law is truly implemented by all 
parties because the validity of the law cannot be measured juridically, but is measured sociologically and philosophically [5]. As stipulated in Article 4 of the Manpower Law, the objectives of the employment law are: 1) To empower and utilize the workforce optimally and humanely; 2) realizing equal distribution of job opportunities and the provision of manpower under the needs of national and regional development; 3) Provide protection to workers, and 4) Improve the welfare of workers and their families [6].

Although the provisions of the Act have determined the purpose of employment, in practice problems often arise that are faced by workers, so the government tries with all efforts to resolve the problems faced by workers, especially when workers/laborers experience termination of employment [7]. Termination of employment is the termination of the employment relationship due to certain reasons that result in the termination of the rights and obligations between the worker/ labourer and the entrepreneur [8]. Termination of employment is something that is not expected by the worker/ labourer, because this will cause them to lose their livelihood, source of livelihood for his family [9]. For this reason, all parties involved in the employment relationship such as entrepreneurs, workers/laborers, trade/labour unions, the government, must make every effort to prevent termination of employment [10].

Termination of employment is unavoidable as a result of the Covid-19 pandemic, resulting in entrepreneurs in Indonesia experiencing losses in their business even to the point of not being able to continue their business due to the prohibition on carrying out activities or social distancing from the government, which also affects workers/labor. According to Sudiarawan [11] that laid off are one of the reasons for industrial relation disputes between the companies and the employees. One of the reasons for a company to terminate the employment is for the efficiency of the company.

Moreover, termination of employment due to expropriation is complemented by the provisions of Article 163 of the Manpower Law, without giving room for objections to workers. Termination of employment that occurs between employers and workers can lead to industrial relations disputes, especially disputes regarding termination of employment [12]. For this reason, it is necessary to protect workers' rights which have been guaranteed in the 1945 Constitution of the Republic of Indonesia, namely fair legal certainty and equal treatment of workers/labour. termination of employment for workers/labourers related to the covid-19 pandemic. Therefore, it is necessary to know what will be the government's policy towards workers/laborers who have been laid off due to the COVID-19 pandemic.

\section{Results and Discussion}

\subsection{Employment Relations and Termination of Employment}

Termination of employment is a dilemma for both companies and employees, because the company will lose the human resources that have been trained so that the company's productivity decreases and for employees will experience stress because they feel their future is bleak [13]. While the employment relationship is a relationship between workers/labour, after a work agreement has been made. While a work agreement is an agreement between workers/labourers and the company or employer that contains the working conditions [14], rights and obligations of the parties (Article 1 point 14 of the Manpower Act). Parties to the Employment Agreement. 


\section{Workers/Labourers}

Worker/Labourer is every person who has worked and does work under orders to carry out his duties by getting wages and receiving compensation in other forms. This definition is under the definition of worker/labourer in Article 1 point 3 of the Manpower Act which states that a worker/labourer is any person who works by receiving wages or other forms of remuneration.

\section{Company}

According to the Manpower Act, Article 1 point 6 states that a company is: 1) Any form of business that is a legal entity or not, owned by an individual, owned by a partnership, or owned by a legal entity, either privately owned or owned by the State that employs workers/laborers by paying wages or other forms of compensation. ; 2) social enterprises and other businesses that have management and employ other people by paying wages or other forms of remuneration.

Therefore, it can be concluded that a company is any form of business with a legal entity or non-legal entity, individually owned, owned by a partnership or owned by a legal entity (private or state) that has management and employs workers/laborers by paying wages or other forms of compensation.

\subsection{The Legal terms of the Agreement}

Based on Article 51 of the Manpower Act, the Employment Agreement is made in writing or verbally. The written or written work agreement is carried out under the applicable laws and regulations. The conditions for a valid work agreement are divided into 2 (two), namely material requirements and formal requirements.

The material requirements are regulated in Article 52 paragraph (1), including: 1) The agreement of both parties. 2) Ability or ability to perform legal actions; 3) The existence of the promised work and 4) the agreed work does not conflict with public order, decency, and the applicable laws and regulations. If the work agreement conflicts with letters a and $b$, then the work agreement can be canceled. If the work agreement conflicts with letters $\mathrm{c}$ and $\mathrm{d}$, then the work agreement is null and void.

Formal requirements are regulated in Article 54 paragraph (1) of the Manpower Act, which states that a written work agreement must at least contain: 1) Name, company address, and type of business; 2) Gender, age, address of the worker/labourer; 3) Position or type of work; 4) Place of work and 5) Amount of wages and method of payment; 6) Terms and conditions of work that contain the rights and obligations of employers and workers; 7) Commencement and period of validity of the work agreement; 8) Place and date the work agreement was made and 9) Signature of the parties in the work agreement.

\subsection{Work Termination}

Termination of Employment Relationship based on the provisions of Article 1 number 25 of the Manpower Act is the termination of the employment relationship due to a certain matter which results in the termination of the rights and obligations between the worker/labourer and the entrepreneur. During the Covid-19 pandemic, there were many layoffs which would certainly have psychological, economic and financial impacts such as workers losing their livelihoods, looking for new jobs, instead having to spend a lot of money, losing living costs for themselves and their families before getting a job. new job.

The manpower law actually stipulates in Article 151 paragraph (1) that entrepreneurs, workers/labour, trade unions/labour unions and the government must make every effort to 
prevent termination of employment for workers. This also mandates that the government, employers, workers and labour unions try to avoid termination of employment and employment relationships so as not to cause economic problems for workers.

Mass layoffs during the Covid-19 Pandemic is not the right step, for that the government and employers are trying to prevent layoffs and work relations by providing solutions, namely,

a. Reduce wages

b. limiting and eliminating overtime

c. reduce working hours

d. lay off and lay off workers in rotation for a while

e. not extending the contract period of workers whose contract period has expired

f. provide pensions to workers who have entered retirement age.

If various efforts have been made to avoid termination of employment, it must be negotiated with the workers first. If the negotiation is not successful, the entrepreneur may terminate the worker's relationship after obtaining a determination from the industrial relations dispute settlement institution.

\subsection{Government Policy Against Workers/Labourers During the Covid 19 Pandemic}

Termination of employment during the COVID-19 pandemic increased the unemployment rate in Indonesia, thus affecting the welfare of workers and laborers. For this reason, the government issued several policies, including:

1. Pre-employment card

This program started on April 9, 2020 and the beneficiaries are approximately 5.6 million people, especially those affected by layoffs, informal workers, micro-enterprises affected by Covid-19. Layoff victims who are entitled to receive the assistance will be given job training by the government and will be given monthly assistance additional funds for 4 months, totalling 3.55 million rupiah. In order for these benefits to be truly targeted, every preemployment card worker must continue to carry out online job training. The pre-employment card was initially given to the young workforce looking for work, but was later extended to those affected by layoffs. The shift occurred in order to provide assistance to those affected by Covid 19.

\section{Cash labour intensive program (PKT)}

This program strongly supports the productive economy of the village which aims to maintain the income of rural communities and support food production activities for food security in the community during the Covid 19 pandemic. Activities carried out can support the prevention and handling of Covid 19 in villages such as clean water management, village sinks for washing hands, quarantine rooms, making masks, hand sanitizers and so on. Cashintensive work, can be applied massively using village funds. Utilization of village funds can include, namely, as social assistance for affected residents, as well as as cash-intensive programs in the village.

3. Providing incentives

Incentives are given to victims of layoffs through BP Jamsostek. The government will provide funds of 5 million rupiah for participants who have joined BPJS for employment (BP Jamsostek). This government policy is carried out as a legal protection for workers affected by layoffs. Legal protection for workers the labour law distinguishes it into three times:

a. Before working period

Legal protection prior to employment is related to the rights of workers outside the employment relationship with the employer, namely, the right to obtain information on manpower planning as regulated in $\mathrm{s} 7$ to 8 of the Manpower Act. 
b. The right to participate in job training aimed at equipping, enhancing and developing work potential in order to increase the ability, productivity and welfare, including for workers with disabilities by taking into account the type of disability degree and ability of the person with disability concerned

c. The right to take part in a program of expanding job opportunities outside the employment relationship.

4. Legal protection in working period

This legal protection relates to workers' rights after having a working relationship with employers, especially during the covid 19 pandemic, one of which is regulated in SE Menaker 3/2020, namely:

a. For workers who are categorized as people under monitoring, Covid-19, based on a doctor's statement, so they cannot come to work for a maximum of 14 days or according to the standards of the Ministry of Health, their wages are paid in full.

b. For workers who are quarantined because of suspected COVID-19, with a doctor's certificate, their wages are paid in full.

c. For workers who do not come to work because of COVID-19 illness with a doctor's certificate, the wages are paid according to the regulations per legislation.

d. For companies that restrict activities so that some workers do not come to work, wages are paid according to the agreement.

5. Legal protection after work

This legal protection relates to the rights of workers after the termination of employment between workers and employers. Workers who are laid off during the COVID-19 pandemic, should get their rights in full, but in practice many employers only pay half or even not the same once, as a result of the company reducing or discontinuing its business activities, which results in reduced income or no company income, even though the provisions of the Manpower Law Article 156 have stipulated that the company is obliged to pay severance rights to workers, namely: months of wages, and so on until a working period of 8 years or more, 9 months of wages.

In addition to severance pay, workers are also entitled to a period of service award if they have worked for 3 years or more but less than 6 years, then 2 months of wages, 6 years period of kingship but less than 9 years, then 3 months of wages, that's how it is then in multiples of 3 years, up to 24 years of service, 10 months of wages. Not all of these provisions can be carried out by employers during the covid 19 pandemic, so to help the condition of workers/laborers who are affected by termination of employment due to the covid 19 pandemic, the Government issues policy policies as mentioned above.

\section{Conclusion}

Employment Relationship is a relationship between the entrepreneur and the worker/labourer, based on a work agreement that has elements of work, wages and orders. Termination of employment is the termination of the employment relationship due to a certain matter which results in the termination of the rights and obligations between the worker/labourer and the entrepreneur. The government's policy policies to protect workers who have been terminated due to the COVID-19 pandemic include the provision of preemployment cards, which contain government assistance to provide job training to workers/laborers so that they can find work again either independently or at other companies. 
also provide incentives in a certain amount for workers / laborers who are registered in the social security of workers, then the government also provides assistance in the Cash Work Intensive program through the village head/lurah.

\section{References}

[1] "Undang Undang Republik Indonesia Nomor 13 Tahun 2003 tentang Ketenagakerjaan."

[2] W. Asri, Hukum Ketenagakerjaan Pasca Reformasi. Sinar Grafika, 2009.

[3] I. Soepomo, Pengantar Hukum Perburuhan. Jakarta: Djambatan, 1974.

[4] H. Zaeni, Hukum Ketenagakerjaan dalam teori dan praktek di Indonesia. Jakarta: Prenadamedia, 2019.

[5] Z. Asikin, Dasar dasar hukum perburuhan. Jakarta: Raja Grafindo Persada, 1993.

[6] Suratman, Pengantar hukum Ketenagakerjaan Indonesia. Jakarta: RajaGrafindo Persada, 2019.

[7] Maimun, Hukum Ketenagakerjaan. Jakarta: Pradnya Paramita, 2004.

[8] I. Soepomo, Pengantar Hukum Perburuhan. Jakarta: Djambatan, 2013.

[9] Y. . Sunindhia, Masalah PHK dan Pemogokan. Jakarta: Bina aksara, 1998.

[10] L. Husni, Pengantar hukum ketenagakerjaan. Jakarta: PT Raja Grafindo Persada, 2019.

[11] K. A. Sudiarawan, "Termination of Employment-Based on Efficiency in Indonesian Company," $J$. Ilmu Huk., vol. 15, no. 1, 2021.

[12] I. P. R. A. Putra, "Legal Protection of Laborin Employment for Termination of Employment Due to the Acquisition of the Company," Int. J. Law, vol. 3, no. 1, 2020.

[13] M. Muslim, "Dilema Pemutusan Hubungan Kerja Bagi Karyawan," Esensi, vol. 18, no. 3, 2015.

[14] D. Ismatullah, Hukum Ketenagakerjaan. Bandung: CV Pustaka Setia, 2013. 